\title{
Properties of a Virus Inhibitor from Spinach Leaves and Mode of Action*
}

\author{
Facine KALO** and Takeshi TANiguchi**
}

\begin{abstract}
A procedure was shown for obtaining inhibitor of virus infection from the sap of spinach leaves. The leaf sap was brought to $50 \%$ saturation with solid ammonium sulfate. The precipitate was suspended in neutral phosphate buffer (PB) and filtrated through a Sephadex G-100 gel column. The active fractions were combined and further purified by DEAE cellulose and CM-Sephadex C-25 column chromatographies. The purified inhibitor lost its inhibitory activity by heating at $100 \mathrm{C}$ for $10 \mathrm{~min}$. The inhibitor inhibited TMV infection on bean and tobacco, while it showed no or a little effect on Chenopodium amaranticolor. When the inhibitor was treated on the undersurface of bean leaves and TMV was inoculated on the uppersurface, the weak inhibitory activity was observed. The inhibitor adsorbed on the leaf surfaces could not be easily removed by Triton X-100 treatment. The inhibitor also showed inhibitory activity to TMV-RNA infection on bean leaves. This reaction was not due to contamination of ribonuclease in the inhibitor preparation.
\end{abstract}

(Received September 17, 1986)

Key words : virus inhibitor from spinach, inhibitory action.

\section{Introduction}

Substances that interfere with plant virus infection occur in many higher plants ${ }^{1)}$. However, only a few of the inhibitory substances have been isolated ${ }^{8,11,13,14,16,17,19)}$ and fewer have been studied for their mode of action during the infection process of virus $^{5-7,10,12,18)}$.

Sap of spinach leaves is known to inhibit infectivity of mechanically transmissible plant viruses. The character of the inhibitor in spinach has been studied in the unpurified state $^{9)}$ and some attempts have been made to isolate the material from the plant sap responsible for inhibition ${ }^{15,16)}$. Recently Straub et al. (1986) ${ }^{13)}$ reported the isolation and characterization of a virus inhibitor from spinach.

In the previous paper ${ }^{16)}$, we reported the nature of the inhibitor in spinach which had been partially purified from the precipitate obtained by $50-100 \%$ ammonium sulfate saturation. In addition, inhibitory activity was also observed in the precipitate obtained by lower concentrations of ammonium sulfate.

This paper describes a method for isolating virus inhibitor in precipitates obtained from spinach sap by $50 \%$ saturation with ammonium sulfate and the mode of action of

* A part of this study was presented at the Annual Meeting of Phytopathological Society of Japan, Nagoya, April 2-4, 1986.

** Faculty of Agriculture, Nagoya University, Nagoya 464, Japan 名古屋大学農学部 
the inhibitor in the process of virus infection.

\section{Materials and Methods}

Virus. Tobacco mosaic virus-ordinary strain (TMV) was propagated in tobacco plants (Nicotiana tabacum cv. Bright Yellow). The leaves infected with TMV were homogenized with water and TMV was purified by the procedure described previously ${ }^{4}$. TMV-RNA was prepared by the method of Gierer and Schramm²).

Plants. French bean plants (Phaseolus vulgaris L. cv. Otebo) were grown in a greenhouse for about 2 weeks after sowing. Tobacco plants (Nicotiana tabacum L. var. Samsun NN) were also grown in a greenhouse. Spinach plants (Spinacia oleracea L.) were obtained from a market.

Estimation of inhibitory activity. The inhibitory activity of inhibitor fractions was estimated by mixing solutions to be tested with equal volumes of TMV $(25 \mu \mathrm{g} / \mathrm{ml})$ in $0.1 \mathrm{M}$ phosphate buffer, $\mathrm{pH} 7.0$ (neutral $\mathrm{PB}$ ) and making half-leaf comparisons on bean and/or tobacco leaves. Control half leaves were inoculated with the same virus solution diluted with equal volumes of the same buffer. After that, the leaves were washed with tap water.

Chromatography on a gel-filtration column. Sephadex G-100 (Pharmacia, Sweden) were suspended in water and packed into a column $(44 \times 1.8 \mathrm{~cm})$. The procedure for gel filtration of samples was described previously ${ }^{16}$. The elution was carried out with the same buffer at a flow rate of $0.5 \mathrm{ml} / \mathrm{min}$. Four milliliters each of the eluted fractions were collected and their absorbance was measured at $280 \mathrm{~nm}$.

Chromatography on ion-exchanger columns. A column $(20 \times 1.5 \mathrm{~cm})$ of DEAE cellulose (Brown Chemical, USA) was prepared as described before ${ }^{16)}$. It was suspended in water and the finer particles in the suspension were removed by decantation. The slurry was poured into a glass tube. The column was washed with $200 \mathrm{ml}$ of $0.1 \mathrm{M}$ $\mathrm{NaOH}$ and $200 \mathrm{ml}$ of water in that order. The column was then equilibrated with neutral $\mathrm{PB}$.

A column $(33 \times 1.5 \mathrm{~cm})$ of $\mathrm{CM}$-Sephadex C-25 gel (Pharmacia, Sweden) was prepared as that of DEAE cellulose and washed with $100 \mathrm{ml}$ of $0.1 \mathrm{~N} \mathrm{NaOH}, 200 \mathrm{ml}$ of water, $100 \mathrm{ml}$ of $0.1 \mathrm{~N} \mathrm{HCl}$ and $200 \mathrm{ml}$ of water in that order. The pretreated column was then equilibrated with $0.05 \mathrm{M} \mathrm{PB}, \mathrm{pH} 6.5$.

Determination of protein concentration. The concentration of protein in samples was determined by the micro biuret method ${ }^{32}$.

\section{Results and Discussion}

\section{Isolation procedures of an inhibitor}

\section{(1) Precipitation by ammonium sulfate}

Frozen spinach leaves were homogenized in neutral PB (about $2 \mathrm{ml} / \mathrm{g}$ tissue) in a Waring blender. The homogenate was filtrated through gauze and centrifuged at $10,000 \times g$ for 20 minutes (unless otherwise stated, centrifugation was carried out at the 
same speed and for the same time). The supernatant was brought to $50 \%$ saturation with solid ammonium sulfate added slowly with stirring. The resultant precipitate was dissolved in neutral PB followed by centrifugation.

\section{(2) Gel-filtration through a Sephadex G-100 column}

The inhibitor fraction obtained by the procedure of ammonium sulfate precipitation was then layered onto the top of the column which had been equilibrated with neutral PB. The chromatogram is shown in Fig. 1. There were two main peaks and the inhibitory activity was observed between them.

\section{(3) Ion-exchange column chromatographies}

The active fractions obtained by gel filtration in Fig. 1 were combined and layered onto the top of a DEAE cellulose column which had been equilibrated with neutral PB. The materials were stepwisely eluted with $50 \mathrm{ml}$ of neutral $\mathrm{PB}, 50 \mathrm{ml}$ of $0.5 \mathrm{M} \mathrm{NaCl}$ in

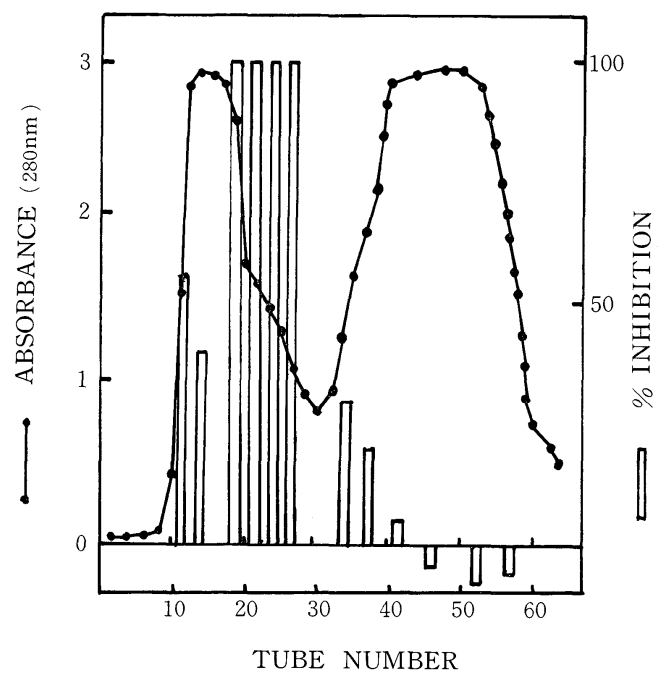

Fig. 1. Gel filtration chromatography of the fraction precipitated from the extract of spinach leaves by $50 \%$ saturated ammonium sulfate on a Sephadex G100 column and $\%$ inhibition of TMV infection by the effluents. Solvent: 0.1M phosphate buffer, $\mathrm{pH}$ 7.0.

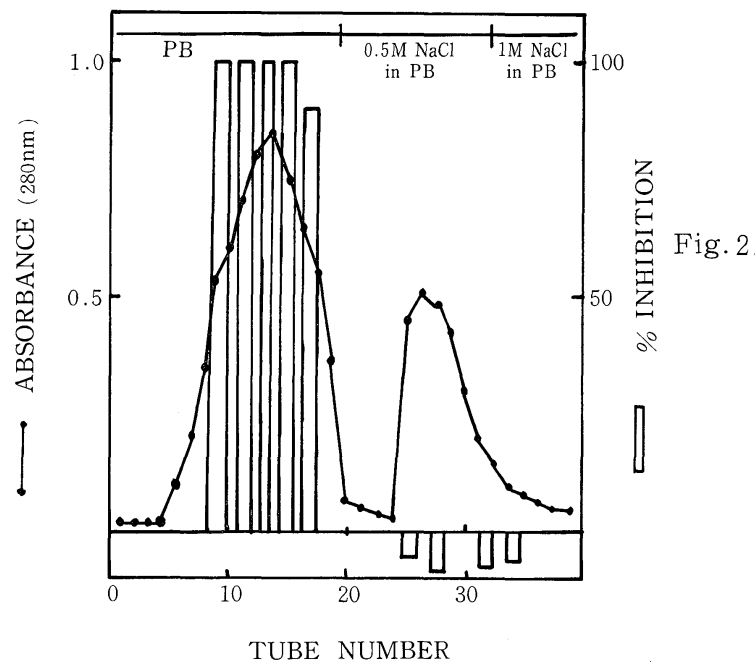

DEAE cellulose column chromatography of the inhibitor fraction obtained by Sephadex G-100 gel filtration chromatography in Fig. 1 and \% inhibition of TMV infection by the effluents. Solvents: $0.1 \mathrm{M}$ phosphate buffer, $\mathrm{pH} 7.0$, and $0.5 \mathrm{M} \mathrm{NaCl}$ and $1 \mathrm{M} \mathrm{NaCl}$ in the same buffer. 


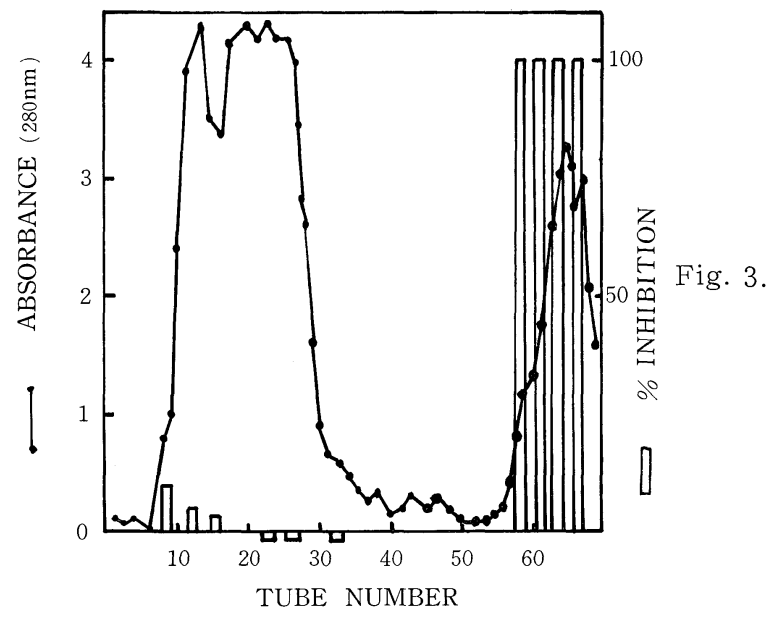

CM-Sephadex C-25 column chromatography of the inhibitor fraction obtained by DEAE cellulose column chromatography in Fig. 2. Solvents: 0.05M phosphate buffer, $\mathrm{pH} 6.5$ and $0.5 \mathrm{M}$ $\mathrm{NaCl}$ in the same buffer.

neutral $\mathrm{PB}$ and $100 \mathrm{ml}$ of $1 \mathrm{M} \mathrm{NaCl}$ in neutral PB. Two peaks were obtained and the inhibitory activity was observed in the fractions in the first peak which did not adsorb on the column (Fig. 2).

The active fractions from DEAE cellulose column were combined and dialyzed against $50 \mathrm{mM}$ phosphate buffer, $\mathrm{pH} 6.5$, overnight. After centrifugation, they were layered onto a CM-Sephadex C-25 column which had been equilibrated with the same buffer. There were two main peaks in the chromatogram and the inhibitory activity was found in the fractions in the second peak which was adsorbed on the column and eluted with $0.5 \mathrm{M} \mathrm{NaCl}$ in the same buffer (Fig. 3). The active fractions were combined and dialyzed against neutral PB overnight, followed by centrifugation. The supernatant solution was used as the inhibitor preparation in the later experiments.

The inhibitor was precipitated by ammonium sulfate and adsorbed on CM-Sephadex $\mathrm{C}-25$ in the isolation procedure. It also gave positive biuret and ninhydrin tests. These results indicate that the inhibitor may be constituted of protein. Therefore, the concentration of the inhibitor was indicated in tables by protein concentration.

\section{Effect of heating the inhibitor on its activity}

The inhibitor was heated at a given temperature for $10 \mathrm{~min}$ in a water bath. After cooling, the inhibitory activity of each sample was tested. No detectable change was found at 40,50 and $60 \mathrm{C}$, while the activity of the sample heated at $100 \mathrm{C}$ was completely lost. The sample heated at $70 \mathrm{C}$ had the activity to some extent (Fig. 4). Moreover, the lower activity was still observed after heating at $70 \mathrm{C}$ for $30 \mathrm{~min}$.

Kuntz and Walker ${ }^{9}$ reported that the thermo-labile inhibitory activity in spinach juice was completely destroyed at $70 \mathrm{C}$ for $12 \mathrm{~min}$. Recently Straub et al. ${ }^{13)}$ reported that purified inhibitor from spinach was completely inactivated by heating at $70 \mathrm{C}$ for $30 \mathrm{~min}$. It is not clear why the difference in the heat-stability of those inhibitor preparations occur.

\section{Estimation of an approximate value of molecular weight}

The inhibitor was chromatographed on Bio-Gel P-60 (Bio Rad, USA) column (44× $2 \mathrm{~cm}$ ) which had been equilibrated with $\mathrm{PB}$. One peak was obtained on the chromato- 


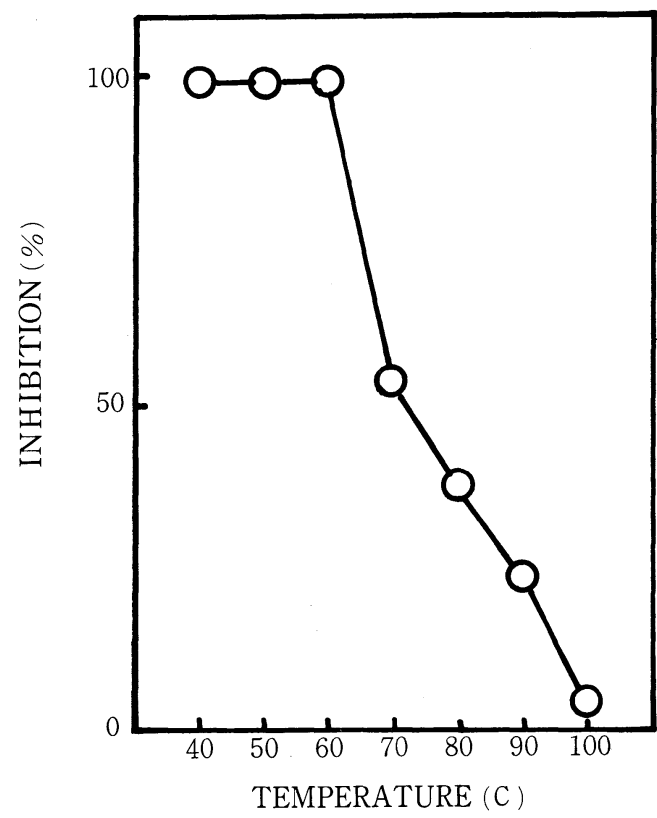

Fig. 4. Effect of heat-treatment of the inhibitor from spinach on its inhibitory activity. The inhibitor in $0.1 \mathrm{M}$ phosphate buffer, pH 7.0 was heated in a water bath for $10 \mathrm{~min}$ at indicated temperatures. Each point represents the average of eight determinants in three experiments.

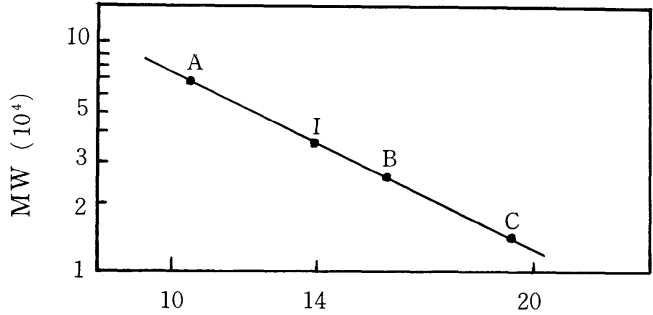

TUBE NUMBER
Fig. 5. Estimation of molecular weight of the inhibitor. Semilog plots of molecular weight against tube number of materials in Bio-Gel P-60 gel filtration chromatography. A: Bovine serum albumin (MW 67,000), I: Inhibitor (MW 40,000), B: Chymotrypsinogen A (MW 25,000), C: RNase (MW 13,000)

gram but the peak was not sharp. The tube number of the highest position of the peak was 14. Fig. 5 shows the relationship between molecular weight of proteins and their tube numbers. From this figure the highest position of peak of the inhibitor corresponds to molecular weight of about 40,000.

\section{Specificity of action of the inhibitor}

The inhibitor showed some specificity of action when plants were treated with a mixture of TMV and the inhibitor. When C. amaranticolor was treated with the inhibitor, the inhibitory activity was not found or very low. On the other hand, the infection of tobacco and bean leaves with TMV was inhibited. It has been known that plant virus inhibitors obtained from higher plants are not generally active in inhibiting infection of the species of their origin, or closely related species.

C. amaranticolor and spinach belong to the same family, Chenopodiaceae. Therefore, the fact that the inhibitor from spinach is not active on $C$. amarnticlor may be explained by their taxonomical relationship. 


\section{Treatment with the inhibitor before or after TMV inoculation}

The inhibitor applied before inoculation had an inhibitory effect against TMV infection. French bean half leaves were rubbed with a piece of synthetic sponge containing the inhibitor in PB without Carborundum and kept for $10 \mathrm{~min}$. The opposite leaves were rubbed with neutral $\mathrm{PB}$ as controls. After washing with water, the leaves were inoculated with TMV at various intervals. The infection was inhibited at any time tested (Table 1).

In the case of the treatment after inoculation, the inoculated leaves were washed with water and then water on the leaves was removed by filter paper. The leaves were treated with the inhibitor and kept for $10 \mathrm{~min}$ followed by washing with water. A strong inhibitory activity was found on the leaves treated immediately after inoculation. However, a little or no effect was found at more than 3 hours after inoculation (Table 1). The result is in accordance with that obtained by Straub et al. ${ }^{13)}$

\section{Inhibitor-treatment on the underside of bean leaves}

The undersurface of bean leaves was rubbed with a piece of synthetic sponge containing the inhibitor in PB immediately or 1 day before inoculation. TMV was then inoculated on the uppersurface of the leaves (Table 2). In this experiment, some degree of the inhibition to virus infection was observed but not so strong. The inhibitor did not directly contact with virus on the leaf surface. Therefore, this result indicates

Table 1. Inhibition of TMV infection by the inhibitor from spinach before or after inoculation

\begin{tabular}{l|l|l|c}
\hline $\begin{array}{l}\text { Inhibitor } \\
\text { conc. }(\mathrm{mg} / \mathrm{ml}) \text { a) }\end{array}$ & $\begin{array}{l}\text { Test } \\
\text { plant }\end{array}$ & $\begin{array}{l}\text { Time of application before or } \\
\text { after inoculation }\end{array}$ & Inhibition of infection (\%)b) \\
\hline \multirow{2}{*}{0.04} & Bean & Immediately before & 98 \\
& & 3 hours before & 97 \\
& & 8 hours before & 98 \\
& & Immediately after & 84 \\
& & 3 hours after & 23 \\
& & 8 hours after & 16 \\
\hline
\end{tabular}

a) Inhibitor concentration was determined by microbiuret method.

b) Each value represents the average of eight determinants in three experiments.

Table 2. Inhibition of TMV infection by the inhibitor from spinach when the inhibitor was treated on the undersurface of bean leaves and then TMV was inoculated on upper one

\begin{tabular}{l|c|c|c}
\hline \hline $\begin{array}{l}\text { Inhibitor } \\
\text { conc. }(\mathrm{mg} / \mathrm{ml})^{\text {a) }}\end{array}$ & $\begin{array}{l}\text { Time of application before } \\
\text { inoculation }\end{array}$ & Treatments & $\begin{array}{l}\text { Inhibition of } \\
\text { infection }(\%) \mathbf{b})\end{array}$ \\
\hline \multirow{2}{*}{0.04} & Immediately & PB (Control) & - \\
& One day & Inhibitor & 65 \\
& & PB (Control) & - \\
& & Inhibitor & 76 \\
\hline
\end{tabular}

a, b) See the note of Table 1 . 
that the inhibitor may partly react with host plant and partly interfere with virus infection and/or virus multiplication.

\section{The effect of Triton $X-100$ on the inhibitory activity of the inhibitor}

Triton X-100 (0.5\%) was mixed with the inhibitor and was rubbed on bean leaves with sponge containing the mixture. After $10 \mathrm{~min}$, the leaves were washed with water and then inoculated with TMV. Control leaves were treated with a mixture of the inhibitor and neutral PB and inoculated with TMV. Table 3 shows that both samples

Table 3. The effect of Triton X-100 on the inhibitory activity of the inhibitor from spinach when mixed with the detergent

\begin{tabular}{l|l|l|c|c}
\hline $\begin{array}{l}\text { Inhibitor } \\
\text { conc. }(\mathrm{mg} / \mathrm{ml})^{\mathrm{a})}\end{array}$ & $\begin{array}{l}\text { Test } \\
\text { plant }\end{array}$ & \multicolumn{1}{|c|}{ Treatments } & No. of lesions & $\begin{array}{l}\text { Inhibition of } \\
\text { infection }(\%)^{\mathbf{b})}\end{array}$ \\
\hline \multirow{2}{*}{0.04} & Bean & PB & 170 & - \\
& & Inhibitor + PB & 8 & 95 \\
& & Inhibitor + TX 100 & 5 & 97 \\
\hline
\end{tabular}

a, b) See the note of Table 1 .

Table 4. The effect of Triton X-100 on the inhibitory activity of the inhibitor from spinach after inhibitor treatment on bean leaves

\begin{tabular}{c|l|l|c|c}
\hline $\begin{array}{l}\text { Inhibitor } \\
\text { conc. }(\mathrm{mg} / \mathrm{ml})^{\text {a) }}\end{array}$ & $\begin{array}{l}\text { Test } \\
\text { plant }\end{array}$ & \multicolumn{1}{|c|}{ Treatments } & No. of lesions & $\begin{array}{l}\text { Inhibition of } \\
\text { infection }(\%) \text { b) }\end{array}$ \\
\hline \multirow{2}{*}{0.04} & Bean & PB & 197 & - \\
& & Inhibitor & 3 & 98 \\
& & Inhibitor before TX100 & 5 & 97 \\
\hline
\end{tabular}

a, b) See the note of Table 1 .

Table 5. Inhibition of TMV-RNA infection on bean leaves by the inhibitor from spinach

\begin{tabular}{l|l|r|r|r}
\hline \multirow{2}{*}{$\begin{array}{l}\text { Inhibitor } \\
\text { conc. }(\mathrm{mg} / \mathrm{ml})\end{array}$} & \multirow{2}{*}{ Plants } & \multicolumn{2}{|c|}{ No. of lesions/half-leaf $\mathrm{b})$} & $\begin{array}{l}\text { Inhibition of } \\
\text { infection }(\%)\end{array}$ \\
\cline { 3 - 5 } & Control & Treatment & 100 \\
\hline 0.04 & Bean & 64 & 0 & 98 \\
\hline
\end{tabular}

TMV-RNA and the inhibitor were mixed immediately before inoculation.

a, b) See the note of Table 1 .

Table 6. Restoration of infectivity of TMV-RNA by phenol treatment of a mixture of TMV-RNA and the inhibitor from spinach

\begin{tabular}{l|c|c|c}
\hline $\begin{array}{l}\text { Inhibitor } \\
\text { conc. }(\mathrm{mg} / \mathrm{ml})^{\text {a) }}\end{array}$ & $\begin{array}{l}\text { Test } \\
\text { plant }\end{array}$ & Treatments & No. of lesions/half-leaf $\mathbf{b})$ \\
\hline 0.04 & Bean & TMV-RNA+PB & 66 \\
& & TMV-RNA+Inhibitor & 0 \\
& & TMV-RNA+Inhibitor + Phenol & 36 \\
\hline
\end{tabular}

a, b) See the note of Table 1 . 
strongly inhibited TMV infection. This means that Triton $\mathrm{X}-100$ does not affect the inhibitory activity of the inhibitor under the conditions.

French bean leaves were dipped into Triton X-100 (0.5\%) for $5 \mathrm{~min}$ and washed with water. The leaves were then inoculated with TMV. Control leaves were dipped into distilled water in place of Triton $X-100$. There were no detectable differences between the number of lesions produced on the control and Triton X-100-treated leaves. This result indicates that Triton $\mathrm{X}-100$ at this concentration does not give any effect on the leaves inoculating with virus.

French bean leaves were treated with the inhibitor, washed with water, and then dipped into $0.5 \%$ Triton $\mathrm{X}-100$ solution for $5 \mathrm{~min}$ for the purpose of removing the inhibitor attached on the leaf surface, followed by washing with water. The leaves were then inoculated with TMV. Control leaves were treated with water in place of Triton $\mathrm{X}-100$. In this experiment, no detectable changes in the number of local lesions occurred on the detergent-treated leaves compared with those of control (Table 4). From these results, it is supposed that the inhibitor may firmly bind with the cells or may enter the cells.

\section{Recovery of TMV infectiviy}

When a mixture of TMV and the inhibitor was gel-filtrated through a column of Sephadex G-100, the separated TMV fraction showed infectivity again. The experiments were conducted three times. TMV separated from mixture with the inhibitor always showed about 90 percent of the infectivity of untreated TMV. The results mean that the inhibitor does not irreversibly inactivate virus particles.

\section{Effects of the inhibitor on TMV-RNA infection}

TMV-RNA was mixed with the inhibitor and then inoculated on bean leaves as described above. Table 5 shows that the inhibitor also inhibits TMV-RNA infection.

A mixture of TMV-RNA and the inhibitor was mixed with water-saturated phenol and centrifuged. The obtained water phase was again mixed with phenol followed by centrifugation. The phenol was then extracted by ether from the water phase. The RNA fraction (water phase) showed infectivity again (Table 6). Therefore, the inhibitory activity of the inhibitor was not due to the contamination of ribonuclease.

Straub et al. ${ }^{13)}$ also reported that an inhibitor from spinach inhibited TMV-RNA infection but they did not examine the contamination of ribonuclease in their preparation.

When virus particles infect plant, uncoating of particles may be necessary for the infection process. Infection by TMV particles as well as TMV-RNA was inhibited by the inhibitor. This fact indicates that the inhibition process may not relate to the uncoating process of infection.

The authors are greteful to professor S. Nishimura, Nagoya University, for valuable advices.

\section{Literature cited}

1. Bawden, F. C. (1954). Advan. Virus Res. 2:31-37.

2. Gierer, A. and Schramm, G. (1956). Nature $177: 702-703$. 
3. Goa, J. (1953). Scand. J. Clin. Lab. Invest. $5: 218-222$.

4. Goto, T. and Taniguchi, T. (1971). Japan. J. Microbiol. 15 : 443-448.

5. Grasso, S., Jones, P. and White, R. F. (1980). Phytopath. Z. $98: 53-58$.

6. Grasso, S. and Shepherd, R. J. (1978). Phytopathology $68: 199-205$.

7. Irvin, J. D. (1975). Arch. Biochem. Biophys. 169:522-528.

8. Kassanis, B. and Kleczkowski, A. (1948). J. gen. Microbiol. $2: 143-153$.

9. Kuntz, J. E. and Walker, J. C. (1947). Phytopathology $37: 561-579$.

10. Owens, R. A., Bruening, G. and Shepherd, R. J. (1973). Virology $56: 390-393$.

11. Ragetli, H. W. J. and Weintraub, M. (1962). Virology $18: 232-240$.

12. Ragetli, H.W. J. and Weintraub, M. (1962). Virology $18: 241-248$.

13. Straub, P., Adam, G. and Mundry, K. W. (1986). J. Phytopathol. $115:$ 357-367.

14. Taniguchi, T. and Goto, T. (1976). Ann. Phytopath. Soc. Japan 42:42-45.

15. Taniguchi, T. and Sumiya, T. (1976). Proc. Kansai P1. Prot. Soc. $18: 18-22$.

16. Taniguchi, T. (1977). Proc. Kansai P1. Prot. Soc. 19:27-32.

17. Taniguchi, T. and Goto, T. (1979). Ann. Phytopath. Soc. Japan $45: 135-141$.

18. Van Kammen, A., Noordam D. and Thung, T. H. (1961). Virology $14: 100-108$.

19. Wyatt, S. D. and Shepherd, R. J. (1969). Phytopathology $59: 1787-1794$.

\section{和 文 摘 要}

Facine KALO ・谷口 武: ホウレンソウ葉に含まれるウイルス阻害物質の性質と作用機構

ホウレンソウ葉の搾汁液からウイルス阻害物質の分離法を示した。汁液に固体硫酸アンモニウムを加えて50 \%飽和にした。沈殿を中性燐酸緩衝液に溶かし Sephadex G-100 ゲル沪過を行った。活性のある分画を集め, さらに DEAE セルロースカラムおよび CM-Sephadex C-25 カラムを用いて阻害物質を精製した。阻害物質 は100 C, 10分の加熱で活性を失い，インゲンおよびタバコで TMV 感染阻害作用を示したが, Chenopodium amaranticolor では効果が無かった。阻害物質をインゲン葉の裹側に処理し, 葉の表側にウイルスを接種して あ弱い阻害効果があった。インゲンの葉に吸着した阻害物質は Triton X-100 を処理して屯, 容易に除くこ とはできなかった。阻害物質は TMV-RNA の感染も阻害した。この反応は阻害物質試料へのリボヌクレア 一ゼの混入によるものではなかった。 